sciendo Порівняльна професійна педагогіка 9(2)/2019 Comparative Professional Pedagogy 9(2)/2019

DOI: $10.2478 /$ rpp-2019-0016

Doctor of PE and Sports Pedagogy, Assistant Professor, SEVINCC NAMLI Erzurum Technical University, Turkey Address: 25100-Yakutiye/Erzurum, Turkey E-mail: sevinc.namli@erzurum.edu.tr

\title{
EXAMINATION OF PHYSICAL EDUCATION AND SPORTS UNDERGRADUATE PROGRAMS OF THE BOLOGNA PROCESS COUNTRIES (POLAND-TURKEY CASE)
}

\section{ABSTRACT}

With geographical, cultural and economic benefits, Poland has adapted to the Bologna Process and has been one of the countries most preferred by students in Turkey within the scope of Erasmus. Turkey and Poland Physical Education and Sports Undergraduate Curriculum were analyzed with data from government agencies in both countries. Erasmus program has been prepared within the framework of the European Union in order to ensure the development of higher education institutions, to work jointly between the universities and to eliminate geographical and educational boundaries. Bologna Process, founded in 1998, Turkey's included in 2001, envisages a structure that ensures the mobility of academic staff, comparable, not bounded by country borders, set standards, competitive and very well connected with each other. With over 400 universities, Poland offers a cost-effective and quality education program. Poland's Physical Education and Sports Undergraduate program is 3 years. The curriculum, which has a weighted structure in the Field Training, also includes Professional Knowledge and General Culture courses. Turkey's constant Physical Education and Sports Science program, which is determined by Higher Education Council (YÖK), is 4 years. In addition to the Field Training courses, Professions Knowledge and General Culture courses are also covered by the curriculum. There is one year (2 semesters, 60 ECTS) difference between Turkey and Poland curriculum. This difference is mostly composed of the National course elements in the Professions Knowledge and General Culture parts. The Field Training courses are divided into theoretical and practical applications and are processed at similar rates in both countries.

Keywords: Bologna Process, Erasmus, Polish Education System, Turkish Education System, Physical Education and Sports.

\section{АНОТАЦІЯ}

Плідно використавщи власні географічні, культурні та економічні переваги, Польща приєдналася до Болонського прочесу $і$ є однією з крайн, яка залучає на навчання іноземних студентів, зокрема студентів з Туреччини, до програми «Еrasтиs». У статті проаналізовано освітню программу з фізичного виховання та спорту Туреччини та Польщі на основі даних урядових установ обох країн. Програма «Егаsтиз» була створена Свропейськоим Союзом з метою забезпечити розвиток вищих навчальних закладів, сприяти спільній роботі між університетами та усунути географічні та освітні кордони. Болонський прочес, розпочатий 1998 року, $i$ приєднання до нього Туреччини у 2001 рочі, сприяли появі такої структури, яка забезпечує мобільність академічного персоналу, не обмежену кордонами обох країн, встановлює новітні освітні стандарти й забезпечує конкурентоспроможність майбутніх фахівиів обох країн. 3-понад 400 університетами, Польща пропонуе економічно 
sciendo Порівняльна професійна педагогіка 9(2)/2019 Comparative Professional Pedagogy 9(2)/2019

ефективну та якісну освітню програму. Бакалаврська програма фізичного виховання та спорту в Польщі триває три роки $і$ включає у себе практичну підготовку, фундаментальну підготовку та покращення рівня загальної культури студентів. У Туреччині, освітня програма з фізичного виховання та спорту, схвалена Радою вищої освіти (ҮӦК), триває 4 роки і включає у себе такі ж сладники, як і освітня программа, розроблена польськими фахівцями. Варто зазначити, щзо иі програмі відрізняються між собою у контексті одного навчального року (два семетри, 60 ECTS). Ця відмінність здебільшого стосується елементів освітньої програми з фізичного виховання та спорту, а саме професійних знань та загальної культури. Навчальні курси поділяються на теоретичні та практичні і вивчаються за аналогічними темпами в обох крайнах.

Ключові слова: Болонський процес, Erasmus, система освіти Польщі, система освіти Туреччини, фізичне виховання і спорт.

\section{INTRODUCTION}

In the light of Bologna Process, the purpose of this research is not only to analyze geographical directions between West and the East European countries, but also to review Curriculum of Physical Education and Sports School of Undergraduate universities in Turkey and Poland. Poland is in the position of a bridge of cultural aspects, economic structure, education levels and appropriate living conditions in the scope of Erasmus. In addition, Poland is the most preferred country of higher education by Turkish students.

The research was carried out based on the data received from the official government agency and through examination of the target undergraduate program universities in Turkey and Poland. In the study, at first the classification and identification of the data were carried out and then a framework was formed with the findings and finally interpretation of the findings executed.

THE AIM OF THE STUDY

The aim of the article is to examine physical education and sports undergraduate programs of the Bologna process countries (Poland-Turkey case).

THEORETICAL FRAMEWORK AND RESEARCH METHODS

ERASMUS (European Region Action Scheme For The Mobility Of University Students). Erasmus program is the name of the program, which was created to develop higher education institutions of member countries and candidate countries of European Union and to work as partners. In the following years in order to ensure the elimination of geographical and educational boundaries; it has been restructured as Erasmus + program in 2014 with many subtitles. (Yağc1 et al., 2007).

Since 2014, the Erasmus + program has been established in Europe, which aims to help people in all age groups participating in the program in education, culture and sports. The Erasmus+ project includes 28 EU member states, non-EU program countries and third countries. Turkey takes advantage of the Erasmus + program as a non-EU countries and as do Poland, which is a member of EU. Erasmus+ Program continues in 5 areas that include 3 main and 2 private activities. (Erasmus + Program: General Structure, 2019). These areas;

Main Action 1: Learning Mobility of Individuals.

Main Action 2: Cooperation for Innovation and Change of Good Practices.

Main Action 3: Support for Policy Reform.

Special Action 1: Jean Monnet Program (research and teaching).

Special Action 2: Sports Supports. (Erasmus + Program: General Structure, 2019). 
Within the scope of the activities to be supported in the field of sports, non-profit organizations' applications are accepted especially for non-profit sporting events. (Erasmus + Program: General Structure, 2019).

The aim of the Erasmus + program is; in particular, to improve the education and training in the field of higher education in the countries of the European Union and the other countries participating in the program. It is aimed that the students who are participating in the program will be mutually exchanged and the academic outputs will be used in common. (Yagci, Cetin and Turhan, 2013).

For the country wishing to participate in the program, the prerequisite for the Erasmus + program is to be included in the European Education and Youth Program. Following the approval of the EU Commission, it is necessary to apply with the Erasmus University Charter. Almost all universities in Turkey are included in the Erasmus + program (Middle, 2014).

Bologna Process. The Bologna Process began in 1998 when France, Germany, England and Italy signed the Sorbonne Declaration. One year later it got the name used today after 25 countries signed the Bologna Declaration (1999). Turkey involved in the process officially by signing the Prague Declaration in 2001. (Acquire, 2008).

As of April 2019, the number of member countries is 48 .

Member States participate in the process in accordance with their wishes; without making any protocol, contract or agreement. It is up to the countries to their own wills to implement the objectives or aims of this process, they do not have any binding. (Higher Education Institution, 2019).

The goals of the Bologna Process for creating a competitive and knowledge-based European economy:

- to increase the mobility of students, teaching and managerial staff;

- to compare national training areas;

- to consider the transnational education dimensions;

- to link education and research activities with each other;

- to ensure the establishment of the European Higher Education (EHEA-AYA) and Research Areas (ERA) which continuously monitor the whole process with internal and external stakeholder engagement (Edinsel, 2008).

The aim of the structured and continuously monitored process is to raise academic standards among the countries that are members of the process after they have established the Higher Education Area (EHEA) in Europe. Another task is to reduce the disagreements and make competitive and more attractive education systems. The process does not foresee a uniform type of education system, it aims to protect different elements in the characteristic education systems of countries and wants to create a unity by creating a balance between these differences.

To summarize the main focus points of the process;

- an easy to understand, interdepartmental transition possible and comparable academic degree system (Undergraduate, Graduate, Doctorate);

- a quality assurance that enables students and international participation, taking into account the National Quality Assurance System in compliance with European principles and standards;

- recognition of diplomas and study periods (European Credit Transfer System,

ECTS). (European Higher Education Area, 2019);

- enabling life-long learning; 
sciendo Порівняльна професійна педагогіка 9(2)/2019 Comparative Professional Pedagogy 9(2)/2019

- high employability;

- to create a system that attaches importance to social dimension.

\section{RESULTS}

\section{Examination of the Polish Curriculum}

Poland, which is a geographical and cultural bridge between Eastern and Western Europe, has become one of the most prominent countries in Europe. With indicators such as its robust economic position, high standards of education, significant opportunities and innovations for students, life conditions, transportation, nutrition and cheap housing, Poland is becoming increasingly attractive for students from all countries.

Poland, with low cost, high quality education, the presence of equivalence of the Higher Education Council (YÖK) having more than 400 university, in English, French and Spanish education opportunity, and a member of the Bologna Process that aims to create a European Higher Education area, is a very suitable country for students whose goals are to receive university education abroad. There are world-famous universities in fields such as medicine, language, law, engineering and agriculture. In addition to these, creative and artistic studies, basic and applied research educations are provided. Thanks to the Bologna Process, foreign students who have graduated from Polish Universities gain a diploma that is valid not only in Poland, but also in Europe and in some countries of the world. At the same time, with the advantages of the European Credit Transfer System (ECTS), students studying at the Polish Universities can continue their education in other countries as well.

According to Curriculums of Faculties of Physical Education and Sports in the Warsaw University, Szczecin University and Opole Polytechnic University, the undergraduate education is 180 ECTS (European Credit Transfer System) for 3 years, 6 semesters (30 ECTS for each semester).

The distribution of 180 ECTS for 3 years ( 6 semesters), 40 ECTS for Professional Knowledge, 14 ECTS for General Culture and 126 ECTS for Field Training, are shown in Figure 1.

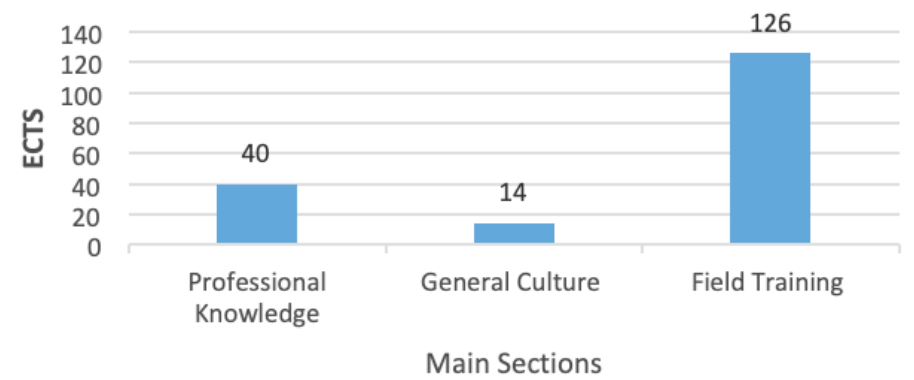

Fig. 1. Main Sections of courses thougt the Polish Universities

Professional Knowledge courses (40 ECTS) mainly consist of Teaching Practice and Internship (17 ECTS) and Introduction to Education, Educational Psychology, Sociology of Education and Philosophy of Education (16 ECTS). Teaching Practice and Internship courses (17 ECTS) are applied 2 days a week for 3 weeks in the Primary and secondary schools in October and November.

General Culture (14 ECTS) consist of Foreign Language and Information Technology courses. 
sciendo Порівняльна професійна педагогіка 9(2)/2019 Comparative Professional Pedagogy 9(2)/2019

Field Education courses (126 ECTS) are divided into two part as a theory (60 ECTS) and an application (66 ECTS). The theoretical part consists mainly of Training Knowledge and Health Information courses (22 ECTS) and Anatomy (14 ECTS) courses. The application part consists of the Elective Courses (17 ECTS), Team Sports (12 ECTS), Rhythm Education and Dance, Athletics, Swimming, such as branches and a SummerWinter Camp (6 ECTS). Elective courses (17 ECTS) consists of these; Athletics, skiing and snowboarding, racquet sports, rhythmic gymnastics, football, basketball, handball, volleyball, swimming, aerobics, fitness, demonstration gymnastics and dance. Students prefer 2 or 3 elective courses.

\section{Examination of the Turkish Curriculum}

Physical Education Teaching students in Turkey, are studying at the University Teaching Department of Physical Education and Sport and Physical Education Teaching. The curricula of these departments of universities are determined by the Higher Education Council (YÖK) and the fixed courses are taught at all universities. The undergraduate education is 240 ECTS for 4 years, 8 semesters ( 30 ECTS for each semester). The courses in the curriculum are basically divided into three sections: Professional Knowledge, General Culture and Field Training.

Distribution of 240 ECTS for 4 years (8 semesters); Professional Knowledge (76 ECTS), General Culture (32 ECTS) and Field Training (132 ECTS) and its distribution is presented in Figure 2:

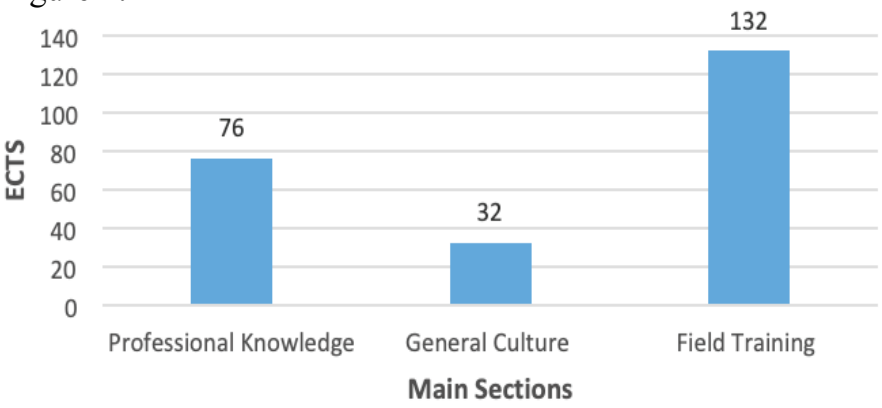

Fig. 2. Main Sections of Courses Taught in Turkish Universities

Professional Knowledge courses (76 ECTS) mainly consist of Teaching Practice and Internship (20 ECTS), elective courses (14 ECTS), Introduction to Education, Educational Psychology, Sociology of Education and Philosophy of Education (12 ECTS). In addition, there are National Education System and History of National Education courses (9 ECTS). Teacher Practice and Internship courses' (20 ECTS) aim is to make observations related to field-specific teaching methods and techniques, to make individual and group micro-teaching applications using these techniques, to prepare activities and materials, to prepare teaching environments and to manage the class. Elective courses (14 ECTS) consist of Child Psychology, Education Law, History of Education, Drama in Education, Critical and Analytical Thinking, Education of Hospitalized Children, Character and Value Education, Out of School Learning Environments, Adult Education and Lifelong Learning.

Half of the General Culture courses (32 ECTS) consists of National History, Ataturk's Principles and History of Turkish Revolution and Turkish Language (16 ECTS). There are also Foreign Language (6 ECTS) and Information Technologies (5 ECTS) courses. 
sciendo Порівняльна професійна педагогіка 9(2)/2019 Comparative Professional Pedagogy 9(2)/2019

Field Training courses (132 ECTS) are divided into two courses: theoretical (75 ECTS) and practice (57 ECTS).

Theoretical part (75 ECTS) mainly consists of Elective Courses (26 ECTS), Motor Development, Skill Learning, Exercise Physiology (20 ECTS), Adapted Physical Education and Sport Training and Health Information courses (13 ECTS) and Physical Training Sports Learning and Teaching Approaches, Teaching Curriculum (13 ECTS). In Theoretical Elective Courses (26 ECTS); there are Physical Training Teaching Models, Drama, Physical Training Sociology, Physical Training and Sport History, Biomechanics, Exercise Psychology and Basic Music Education courses.

In the Practical part (57 ECTS); there are Elective Courses (18 ECTS), Team Sports (10 ECTS), Rhythm Education and Dance, Athletics, Swimming, as well as branches including the Folk Dance courses (3 ECTS). Practical Elective courses (18 ECTS) consist of Traditional Turkish Sports (wrestling, javelin, riding, sled etc.) and Defense Sports courses.

\section{Comparison of Polish and Turkish Curriculum}

When compared to Physical Education and Sports Teaching in Physical Education and curriculum section in Turkey with the Faculty of Physical Education and Sports of th University of Warsaw, Szczecin and Opole in Poland; it is seen that academic years, periods, the total amount of ECTS and the National themed courses in Turkey constitute the main differences. While Turkish curriculum duration is 4 years, 8 semesters and 240 ECTS, the curriculum duration in Polish is 3 years, 6 semesters and 180 ECTS. In both country, each semester consists of 30 ECTS.

Both Turkish and Polish curriculum are divided into three main sections: Professional Knowledge, General Culture and Field Training. The main section courses, which are distributed throughout the years of education, differ in terms of ECTS values and content. Table 1 shows the ECTS values of the courses as well as the sections dedicated to Professional Knowledge, General Culture and Field Training courses (see Table 1).

Table 1

Distribution of the Course in Turkish and Polish Curriculum

\begin{tabular}{|c|c|c|c|}
\hline SECTIONS & COURSE NAME & $\begin{array}{l}\text { TURKEY } \\
\text { ECTS }\end{array}$ & $\begin{array}{l}\text { POLAND } \\
\text { ECTS }\end{array}$ \\
\hline \multirow{7}{*}{$\begin{array}{l}\text { Professional } \\
\text { Knowledge }\end{array}$} & $\begin{array}{l}\text { Introduction to Education and Psychology } \\
\text { of Educatio; Sociology; Philosophy }\end{array}$ & 12 & 16 \\
\hline & $\begin{array}{l}\text { Instructional Technologies; Teaching Principles } \\
\text { and Methods; Research Methods in Education }\end{array}$ & 9 & 4 \\
\hline & $\begin{array}{l}\text { National Elements; National Education System } \\
\text { and School Management; Turkish Education } \\
\text { History; Classroom Management }\end{array}$ & 9 & - \\
\hline & $\begin{array}{l}\text { Ethics in Education; Measurement and } \\
\text { Evaluation }\end{array}$ & 6 & 1 \\
\hline & Teaching Practice and Internship & 20 & 17 \\
\hline & Guidance in Schools & 6 & 2 \\
\hline & Elective Lesson & 14 & - \\
\hline
\end{tabular}


sciendo Порівняльна професійна педагогіка 9(2)/2019 Comparative Professional Pedagogy 9(2)/2019

continued

\begin{tabular}{|c|c|c|c|}
\hline SECTIONS & COURSE NAME & $\begin{array}{l}\text { TURKEY } \\
\text { ECTS }\end{array}$ & $\begin{array}{l}\text { POLAND } \\
\text { ECTS }\end{array}$ \\
\hline & PROFESSIONAL KNOWLEDGE - TOTAL & 76 & 40 \\
\hline \multirow{5}{*}{$\begin{array}{c}\text { General } \\
\text { Culture }\end{array}$} & $\begin{array}{l}\text { National History; Ataturk's Principles and } \\
\text { History of Turkish Revolution; Turkish } \\
\text { Language }\end{array}$ & 16 & - \\
\hline & Foreign Language & 6 & 7 \\
\hline & Information Technologies & 5 & 7 \\
\hline & Community Service Practices & 3 & - \\
\hline & Elective Lesson & 2 & - \\
\hline & $\begin{array}{r}\text { GENERAL CULTURE } \\
\text { TOTAL }\end{array}$ & 32 & 14 \\
\hline \multirow{21}{*}{$\begin{array}{c}\text { Field } \\
\text { Training }\end{array}$} & $\begin{array}{l}\text { Fundamentals of Physical Education and Sport; } \\
\text { Training Information; Health Information and } \\
\text { First Aid; Nutrition }\end{array}$ & 13 & 22 \\
\hline & Anatomy & 3 & 14 \\
\hline & $\begin{array}{l}\text { Physical Education }- \text { Sports Learning and } \\
\text { Teaching Approaches; Curriculum }\end{array}$ & 13 & 9 \\
\hline & $\begin{array}{l}\text { Motor Development; Skill Learning; Exercise } \\
\text { Physiology; Physical Fitness; Movement Training; } \\
\text { Adapted Physical Education and Sports }\end{array}$ & 20 & 10 \\
\hline & Elective Lesson & 26 & 5 \\
\hline & $\begin{array}{r}\text { FIELD TRAINING (THEORETICAL) } \\
\text { TOTAL }\end{array}$ & 75 & 60 \\
\hline & Athletics & 4 & 4 \\
\hline & Gymnastics & 4 & 5 \\
\hline & Team Sports & 10 & 12 \\
\hline & Rhythm Education and Dance & 5 & 5 \\
\hline & Swimming & 3 & 4 \\
\hline & Outdoor Sports & 3 & 4 \\
\hline & Racket Sport & 4 & 3 \\
\hline & Folk Dances & 3 & - \\
\hline & Educational Games & 3 & 4 \\
\hline & \begin{tabular}{|l|} 
Elective Lesson \\
\end{tabular} & 18 & 17 \\
\hline & Summer Camp-Winter Camp & - & 6 \\
\hline & Martial Arts & - & 2 \\
\hline & FIELD TRAINING (PRACTICE) TOTAL & 57 & 66 \\
\hline & FIELD TRAINING TOTAL & 132 & 126 \\
\hline & GENERAL TOTAL & 240 & 180 \\
\hline
\end{tabular}

While Professional Knowledge courses have 76 ECTS in Turkey, they have 40 ECTS in Poland. This is almost twice the value. While General Culture courses have 32 ECTS in Turkey, they have 14 ECTS in Poland. This value is approximately 2.5 times. 
Field Training courses have 132 ECTS in Turkey and they have 126 ECTS in Poland. There is no significant difference between the two curricula in the Field Education courses.

During the study period, the 60 ECTS (240-180) difference in courses taught in Turkish curriculum predominantly occurs in the Professional Knowledge and General Culture courses. This is shown in Figure 3.

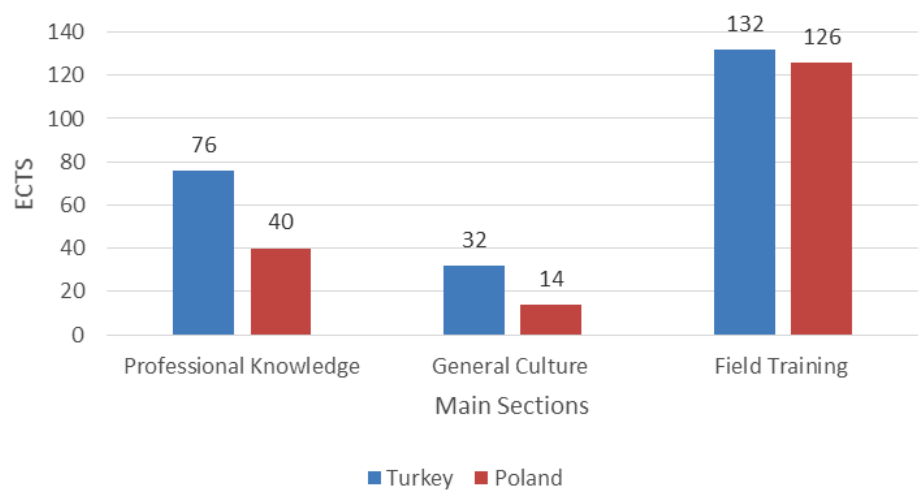

Fig. 3. Main Sections of Turkish and Polish Curriculum

In the Professional Knowledge courses, the teaching practices and internship (20-17 ECTS), the Sociology of Education and the Philosophy of Education (12-16 ECTS) courses are similar in both countries. 36 ECTS (76-40) difference in Turkish curriculum is derived from Elective Lessons (14 ECTS) and the National courses (9 ECTS).

In General Culture courses, the courses of Foreign Language (6-7 ECTS) and Information Technologies (5-7 ECTS) are similar in both countries. 18 ECTS (32-14) difference in Turkish curriculum is derived from National History, Ataturk's Principles and History of Turkish and Turkish Language (16 ECTS) courses (see Figure 4).

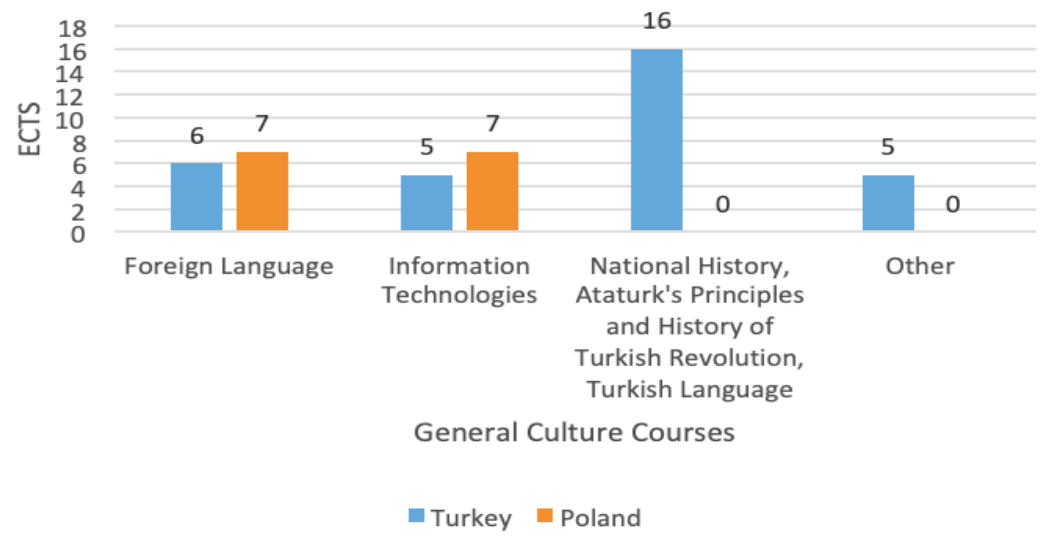

Fig. 4. General Culture Courses in Turkish and Polish Curriculum 
sciendo Порівняльна професійна педагогіка 9(2)/2019 Comparative Professional Pedagogy 9(2)/2019

Field Training courses, are divided into two as Theoretical and Practice, have similar weight (132-126) in both countries. When the Field Training courses analyzed, 18 ETCS (75-57) difference is seen in favor of theoretical part in Turkey. 6 ETCS (66-60) difference is seen in favor of practical part in Poland (see Figure 5).

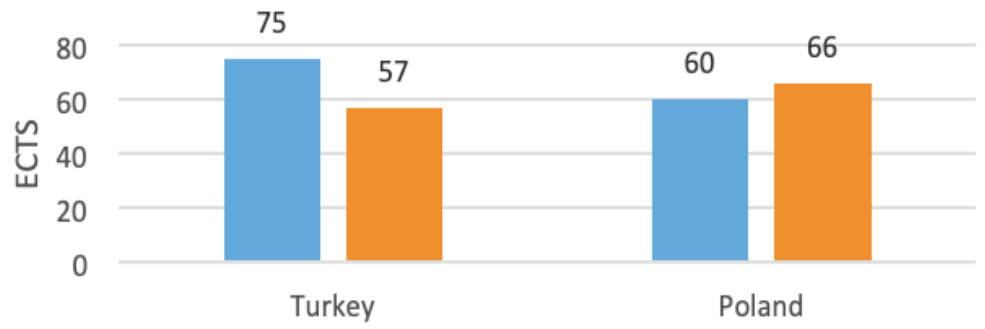

Weight of Theoretical and Practical Courses

Theoretical $\quad$ Practical

Fig. 5. Weight of Theoretical and Practical Courses at Turkey and Poland

The weight of Theoretical Courses of Field Training in Turkey have 15 ECTS (75-60) more than Practical courses. In Theoretical Courses of Field Training, Physical Education Learning and Teaching Approaches course (13-9 ECTS) have similar weight; Motor Development, Skill Education, Exercise Physiology (20-10 ECTS), and Elective Lessons (26-5 ECTS) have relatively more weight in Turkey; Training Information and Health Information courses (13-22 ECTS) Anatomy (3-14 ECTS) courses have relatively more weight in Poland.

The weight of Practical Courses of Field Training in Poland have 6 ECTS (66-60) more than Theoretical Courses. In Practical Courses, Elective Lessons (18-17 ECTS), Athletics (4- 4 ECTS), Gymnastics (4-5 ECTS), Team Sports (10-12 ECTS), Rhythm Education and Dance (5-5 ECTS), Swimming (3-4 ECTS), Nature Sports (3-4 ECTS), Racket Sport (4-3 ECTS) and Educational Games (3-4 ECTS) have similar weight. The main differences in the Practical Cources are folk dances (3 ECTS) in Turkey and Summer-Winter camp (6 ECTS) in Poland. Martial Arts courses in the curriculum Poland (2 ECTS) is located in Elective Lessons in Turkey.

Consequently, the results obtained from the examination and comparison of Turkish and Polish curriculum is as follows:

1.60 ECTS (240-180) difference arises from being more than a year (two semesters) of Turkish curricula, is derived from Professional Knowledge and General Culture courses.

2. The main differences between the curricula are given in Table 2 .

Table 2

Main Differences between Turkey and Poland Curricula

\begin{tabular}{|l|l|l|}
\hline \multicolumn{1}{|c|}{ Criterion } & \multicolumn{1}{|c|}{ Turkey } & \multicolumn{1}{|c|}{ Poland } \\
\hline GENERAL: & It is fixed at each university & $\begin{array}{l}\text { Each university can make changes } \\
\text { to the curriculum }\end{array}$ \\
\hline $\begin{array}{l}\text { Difference } \\
\text { of Curriculum }\end{array}$ & \multicolumn{2}{|c|}{} \\
\hline
\end{tabular}


sciendo Порівняльна професійна педагогіка 9(2)/2019 Comparative Professional Pedagogy 9(2)/2019

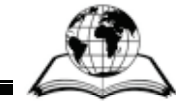

\begin{tabular}{|c|c|c|}
\hline Criterion & Turkey & Poland \\
\hline $\begin{array}{l}\text { Academic year, } \\
\text { Semester }\end{array}$ & 4 Year, 8 Semester & 3 Year, 6 Semester \\
\hline Total ECTS & 240 ECTS & 180 ECTS \\
\hline $\begin{array}{l}\text { Main parts of the } \\
\text { curriculum }\end{array}$ & \multicolumn{2}{|c|}{ Professional Knowledge General Culture Field Training } \\
\hline \multicolumn{3}{|c|}{ PROFESSIONAL KNOWLEDGE: } \\
\hline ECTS & 76 & 40 \\
\hline $\begin{array}{l}\text { Courses } \\
\text { of Similar Weight }\end{array}$ & \multicolumn{2}{|c|}{$\begin{array}{l}\text { Teaching Practice and Internship, } \\
\text { Sociology and Philosophy of Education, }\end{array}$} \\
\hline $\begin{array}{l}\text { Courses of Different } \\
\text { Weights }\end{array}$ & $\begin{array}{|ll|}\text { Elective Lesson; National } \\
\text { Education System and National } \\
\text { Education Cources }\end{array}$ & - \\
\hline \multicolumn{3}{|c|}{ GENERAL CULTURE: } \\
\hline ECTS & 32 & 14 \\
\hline $\begin{array}{l}\text { Courses } \\
\text { of Similar Weight }\end{array}$ & \multicolumn{2}{|c|}{$\begin{array}{c}\text { Foreign Language, } \\
\text { Information Technologies }\end{array}$} \\
\hline $\begin{array}{l}\text { Courses of Different } \\
\text { Weights }\end{array}$ & \begin{tabular}{|l|} 
National History; Ataturk's \\
Principles and History of Turkish \\
Revolution; Turkish Language
\end{tabular} & - \\
\hline \multicolumn{3}{|l|}{ FIELD TRAINING } \\
\hline Total ECTS & 132 & 126 \\
\hline \multicolumn{3}{|l|}{ Theoretical Courses } \\
\hline ECTS & 75 & 57 \\
\hline $\begin{array}{l}\text { Courses } \\
\text { of Similar Weight }\end{array}$ & \multicolumn{2}{|c|}{$\begin{array}{l}\text { Physical Education - Sports Learning and Teaching Approaches, } \\
\text { Curriculum }\end{array}$} \\
\hline $\begin{array}{l}\text { Courses of Different } \\
\text { Weights }\end{array}$ & $\begin{array}{l}\text { Motor Development; Skill } \\
\text { Learning; Exercise Physiology; } \\
\text { Elective Lesson }\end{array}$ & $\begin{array}{l}\text { Training Information and Health } \\
\text { Information, } \\
\text { Anatomy }\end{array}$ \\
\hline \multicolumn{3}{|l|}{ Practical Courses } \\
\hline ECTS & 60 & 66 \\
\hline $\begin{array}{l}\text { Courses } \\
\text { of Similar Weight }\end{array}$ & \multicolumn{2}{|c|}{$\begin{array}{l}\text { Elective Lesson; Athletics; Gymnastics; Team Sports; } \\
\text { Rhythm Education and Dance; Swimming; Outdoor Sports; } \\
\text { Racket Sport; Educational Games }\end{array}$} \\
\hline $\begin{array}{l}\text { Courses of Different } \\
\text { Weights }\end{array}$ & Folk Dances & Summer-Winter Camps \\
\hline
\end{tabular}

\section{CONCLUSIONS}

Some social, cultural, economic and academic justifications make Poland one of the most preferred country by Turkish students in the Erasmus Program. 3 academic years of the undergraduate program, a diploma that is valid in the countries involved in the Bologna Process in Turkey and low cost of living mainly constitute these justifications.

As a result of the comparison and examination of Turkish and Polish curriculum, almost half of the courses are the same or very similar. Differences are mainly due to the Turkish curriculum that is longer. If the National Courses and Elective Lessons are ignored, the similarity ratio is stands out two thirds. 
In Turkish curriculum, there are national courses on General Culture section (folk dances, national sports) in addition to Professional Knowledge and Field Training. The existence of national elements is entirely related to national culture and academic culture. It is very useful and important to shape the education system on national foundations and to transfer this system to the lower generations with the local elements. It should not be expected that the successful academic systems created in any country will have the same results when applied to another country. Successful results can be achieved when successful systems are supported by local and cultural motifs. In this context, additional one more academic year in Turkey should not be considered as a weakness.

The most significant difference in Polish universities is the short duration of the academic period and the presence of summer and winter camps. The importance of camping concept in team sports is unquestionable. It is very beneficial to involve this camp programme in curricula. In addition to increase the physical condition, sport camps strengthen the ties of unity and solidarity within the team and increase personal development and sport success.

\section{REFERENCES}

1. Edinsel, K. ed. (2008). Bologna süreci'nin Türkiye'de uygulanması. Bologna uzmanları ulusal takımı projesi.

2. Eramsus + Program: General Structure. (2019). Retrieved from http://www.ua.gov.tr/ programlar/erasmus-program $\% \mathrm{C} 4 \% \mathrm{~B} 1$.

3. European Commission. (2019). Education and Training. The Bologna Process and European Higher Education Area. Retrieved from https://ec.europa.eu/education/ policies/higher-education/bologna-process-and-european-higher-education-area_en.

4. European Higher Education Area. (2019). Retrieved from http://www.ehea.info/ page-full_members.

$\overline{5}$. Eynur, B. R., \& Muharremoğlu, A. (2009). Dünyada ve Türkiye'de Mevcut Beden Eğitimi Öğretmenliği Eğitim Öğretim Durumu. Beden Eğitimi ve Spor Bilimleri Dergisi, 7 (1). Retrieved from http://dergipark.org.tr/ataunibesyo/issue/28868/308805.

6. Ortaş, İ. (2014). Türkiye İçin Ulusal Bir Erasmus Programı Gerekli mi?. Toplum ve Demokrasi Dergisi, 2 (3), 249-254.

7. Şenel, E., Yildiz, M., Ulaş, M., \& Tamer, K. (2019). The validity and reliability study of the Turkish form of physical education marginalization and isolation scale (PEMAIS). Gazi Journal of Physical Education and Sport Sciences, 24 (3), 155-166.

8. Yağc1, E., Ekinci, C. E., Burgaz, B., Kelecioğlu, H., \& Ergene, T. (2007). Yurt dışına giden Hacettepe Üniversitesi Erasmus öğrencilerinin memnuniyet düzeyleri. Hacettepe Üniversitesi Ĕgitim Fakültesi Dergisi, 33, 229-239.

9. Yağc1, E., Çetin, S., \& Turhan, B. (2013). Erasmus programı ile Türkiye'ye gelen öğrencilerin karşılaş̧ıkları akademík güçlükler. Hacettepe Üniversitesi Ĕgitim Fakültesi Dergisi, 44, 341-350.

10. Yüksek Öğrenim Кигити. (2019). Retrieved from http://bologna.yok.gov.tr/ ?page=yazi\&c $=1 \& \mathrm{i}=3$ ). 